University of Nebraska - Lincoln

DigitalCommons@University of Nebraska - Lincoln

Nebraska Cooperative Fish \& Wildlife Research Nebraska Cooperative Fish \& Wildlife Research Unit -- Staff Publications

2004

\title{
Red Imported Fire Ant Impacts on Wildlife: A Decade of Research
}

C. R. Allen

Clemson University, callen3@unl.edu

D. M. Epperson

Clemson University

A. S. Garmestani

Clemson University, garmestani.ahjond@epa.gov

Follow this and additional works at: https://digitalcommons.unl.edu/ncfwrustaff

Part of the Other Environmental Sciences Commons

Allen, C. R.; Epperson, D. M.; and Garmestani, A. S., "Red Imported Fire Ant Impacts on Wildlife: A Decade of Research" (2004). Nebraska Cooperative Fish \& Wildlife Research Unit -- Staff Publications. 31. https://digitalcommons.unl.edu/ncfwrustaff/31

This Article is brought to you for free and open access by the Nebraska Cooperative Fish \& Wildlife Research Unit at DigitalCommons@University of Nebraska - Lincoln. It has been accepted for inclusion in Nebraska Cooperative Fish \& Wildlife Research Unit -- Staff Publications by an authorized administrator of DigitalCommons@University of Nebraska - Lincoln. 
Am. Midl. Nat. 152:88-103

\title{
Red Imported Fire Ant Impacts on Wildlife: A Decade of Research
}

\author{
C. R. ALLEN ${ }^{1}$ \\ USGS-South Carolina Cooperative Fish and Wildlife Research Unit, Clemson University, Clemson 29634 \\ D. M. EPPERSON \\ South Carolina Cooperative Fish and Wildlife Research Unit, Clemson University, Clemson 29634
}

AND

A. S. GARMESTANI

South Carolina Cooperative Fish and Wildlife Research Unit and Program in Policy Studies, Clemson University, Clemson 29634

\begin{abstract}
The negative impacts of biological invasion are economically and ecologically significant and, while incompletely quantified, they are clearly substantial. Ants (family Formicidae) are an important, although often overlooked, component of many terrestrial ecosystems. Six species of ants are especially striking in their global ability to invade, and their impacts. This paper focuses on the impacts of the most destructive of those species, the red imported fire ant (Solenopsis invicta), and focuses on impacts on native vertebrates. Red imported fire ants often become the dominant ant species in infested areas outside of their native range due to their aggressive foraging behavior, high reproductive capability and lack of predators and/or other strong competitors. The evidence suggests that mammals, birds and herpetofauna are vulnerable to negative impacts from fire ants, and some species are more likely to experience negative population-level impacts than other species. Assessing the ecological impacts of fire ants on wild animal populations is logistically difficult, and very few studies have combined replicated experimental manipulation with adequate spatial ( $>10$ ha) and temporal $(>1$ y) scale. Thus, most studies have been observational, opportunistic, small-scale or 'natural' experiments. However, significant research, including an increase in experimental and mechanistic investigations, has occurred during the past decade, and this has led to information that can lead to better management of potentially affected species.
\end{abstract}

\section{INTRODUCTION}

Biological invasions are a growing threat to human enterprise and ecological systems. The rate of introductions continues to increase, and many countries are developing organized plans to strengthen bio-security in the face of these threats. The negative impacts of biological invasion are economically and ecologically significant and, while they remain incompletely quantified, they are clearly substantial. For example, Pimentel et al. (2001) estimated that the economic costs of non-indigenous species for the United States, the United Kingdom, Australia, South Africa, India and Brazil exceeded US $\$ 314$ billion per y. Ecological and environmental costs are considerably more difficult to quantify, but include the extinction of indigenous biota, disruption of community structure and changes in ecological processes, with concomitant losses of ecosystem services and capital.

Ants (family Formicidae) are an important, although often overlooked, component of many terrestrial ecosystems. They often comprise a large percentage of the animal biomass

\footnotetext{
${ }^{1}$ Corresponding author: Telephone: (864) 656-4461; FAX: (864) 656-1034; e-mail: allencr@ clemson.edu
} 
in some ecosystems (Holldobler and Wilson, 1990) and may be functionally irreplaceable. They provide valuable ecosystem services such as nutrient turnover, energy flow and seed dispersal (Handel et al., 1981). The taxon includes ecologically important predators, scavengers, herbivores, detritovores and granivores. Ants often participate in complex interactions with other species, and there are a surprising array of tightly co-evolved mutualisms between plants and ants. The Formicidae include a relatively large number of introduced or invasive species (>150 species; McGlynn, 1999). Six species of ants are especially striking in their global ability to invade, and their impacts: Anoplolepis gracilipes (crazy ant), Linepithema humile (Argentine ant), Pheidole megacephala (big-headed ant), Solenopsis invicta (red imported fire ant), Solenopsis geminata (tropical fire ant) and Wasmannia auropunctata (little fire ant) (Holway et al., 2002). This paper focuses on the impacts of the most destructive of those species, the red imported fire ant, and focuses on impacts on native vertebrates.

Red imported fire ants (hereafter 'fire ants') were introduced through the port of Mobile, Alabama, in the 1930s (Buren, 1972; Buren et al., 1974). Fire ants are native to South America where their abundance is restricted by competition with other ant species (Buren et al., 1974) and the presence of co-evolved predators (Porter et al., 1997) and enemies (Jouvenaz, 1983). They often become the dominant ant species in infested areas outside of their native range due to their aggressive foraging behavior, high reproductive capability and lack of predators and competitors. In South America, fire ants are predominantly monogynous, meaning that each colony contains only one fertile queen (Jouvenaz et al., 1989; Ross et al., 1996). Density of monogyne fire ants averages about 100 mounds/ha. In the United States, two forms of red imported fire ants exist, monogynous and polygynous (Greenberg et al., 1985; Porter et al., 1991). Density of polygyne fire ants is usually three times or more than that of the single queen form (Macom and Porter, 1996). Polygyne colonies in the United States usually average around 500 mounds/ha (Vinson and Sorenson, 1986; Macom and Porter, 1996) and densities as high as 1400 mounds/ha (Greenberg et al., 1985; Porter et al., 1991) have been recorded. Porter et al. (1992) reported densities in the U.S. to be 35 times higher than densities in South America, and attributed this disparity to the high frequency of polygyne colonies on sites in North America. In Queensland, Australia, colony densities as high as 5000 mounds/ha have been recorded in limited areas (C. Vanderwoude, Fire Ant Control Center, Department of Primary Industries, Queensland, Australia, pers. comm.). The high densities associated with polygyne infestations greatly increase the probability of interaction with, and negative impacts on, native species. However, single queen infestations may have similar, though less obvious, impacts.

Allen $e$ al. (1994) reviewed the impacts of fire ants on native wildlife. That paper covered 13 peer-reviewed papers (also included, due to the limited information available, were agency reports and non-reviewed proceedings) published during the approximately 60-y period beginning with the introduction of the red imported fire ant in the early 1930s. Since then, 47 research papers have been published, greatly expanding knowledge of fire ant impacts on wildlife. In contrast with earlier papers, these more recent papers are more likely to be experimental and investigate mechanisms of impact (Fig. 1). During the past $10 \mathrm{y}$ fire ants have continued to spread at an alarming rate. They have now been documented as present on many Caribbean Islands (Davis et al., 2001), have made the inevitable jump to the West Coast of the United States and successfully invaded Australia in 2001 (Moloney and Vanderwoude, 2002). In the continental United States they have increased their range to more than 132 million ha infested within the United States Department of Agriculture (USDA) quarantine area. This includes 13 states (AL, AR, CA, FL, GA, LA, MS, NC, NM, OK, SC, TN, TX) and Puerto Rico. Fire ants have been detected in other states (AZ, NV), but 


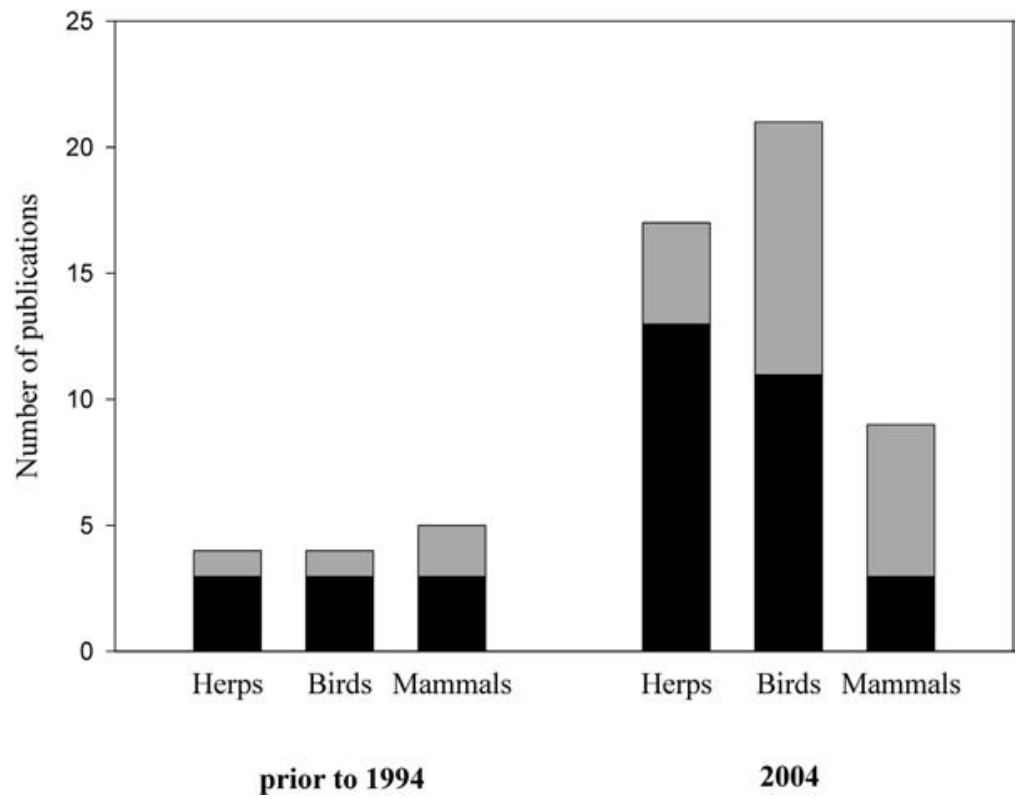

FIG. 1.-Peer-reviewed publications concerning fire ant impacts on native wild vertebrates, separated by taxonomic group. 1994 refers to papers published from the time of fire ant introduction into the United States from approximately 1932 until 1992, reviewed in Allen et al. (1994). 2004 refers to papers published between 1993-2003. Black indicates non-experimental publications and gray indicates experimental publications

those were not quarantined in 2003 (A. Callcott, USDA-APHIS, Gulfport MS, pers. comm.). This paper reviews those papers focusing on the impact of red imported fire ants on wildlife published in the past $10 \mathrm{y}$ (and a couple missed in the original review) and synthesizes the state of our knowledge regarding those impacts as of 2004.

\section{IMPACTS ON REPTILES AND AMPHIBIANS}

The global decline of amphibians and reptiles has been linked to six causal factors: habitat loss and degradation, environmental pollution, disease, global climate change, unsustainable use and introduced invasive species (Gibbons et al., 2000). While many scientists agree that habitat loss is the largest single factor contributing to these declines, the impacts of introduced invasive species may also be substantial.

There are a variety of life history traits that may make both reptiles and amphibians particularly susceptible to fire ants, including egg-laying and the disturbance associated with this activity (Allen et al., 1994), and delayed hatchling emergence. Much experimental and observational data has accumulated since Landers et al. (1980) first reported red imported fire ants preying upon hatchling gopher tortoises. Their observation of ten hatchlings that were "destroyed" by fire ants is typical of earlier publications. Predation occurred when hatchlings hatched from the egg, but had not yet emerged on the soil surface, and before hatchlings could completely emerge from the egg.

While there is some documentation of direct impacts of fire ants on herpetofauna, either by observation or experimentation, indirect impacts may be harder to assess. Indirect 
impacts may include reduced survival and weight gain, behavioral changes, changes in foraging patterns and habitat use and reduced food availability. The first experimental evidence of indirect impacts of fire ants on herpetofauna focused on neonatal American alligators (Alligator mississippiensis). Allen et al. (1997b) tested the hypothesis that envenomization by fire ants has an impact on hatchling alligator survival and body mass. Hatchlings that emerged from nesting material containing red imported fire ants exhibited significantly less weight gain than those from the reference group in the controlled laboratory environment. Alligator nests that contain fire ants may also receive less maintenance by female alligators resulting in reduced nest success. That hypothesis was investigated by Reagan et al. (2000) in southwestern Louisiana. They documented that both female attendance and nest success were lower for alligator nests with fire ants present, supporting the findings of Allen et al. (1997b).

The potential effects of fire ants on turtle species also includes both direct and indirect impacts. Whiting (1994) documented indirect impacts to an adult Pseudomys texana, which abandoned a nesting attempt after being irritated by fire ant stings. Conners (1998a) found six hatchling Chelydra serpentina that had either emerged from the nest or were just below the surface that appeared to have been preyed on by fire ants. While there are few reports of predation on adult turtles, five adult three-toed box turtles (Terrapene carolina triunguis) were killed by fire ants in Texas (Montgomery, 1996). Box turtles (adults and juveniles) may be particularly susceptible to fire ant predation due to their defensive reaction to close the plastron and become immobile. Even a tightly closed box turtle shell has some gaps large enough for fire ants to penetrate and the turtle's immobility allows more fire ants to swarm over it. Fire ant predation on hatchling and juvenile gopher tortoises (Gopherus polyphemus) has been recently documented (Epperson and Heise, 2003).

Both Allen et al. (2001a) and Buhlmann and Coffmann (2001) provided experimental evidence of fire ant impacts on turtles. Allen et al. (2001a) assessed the impacts of fire ants on Florida red-bellied turtle hatchlings, Pseudomys nelsoni. This species is similar to sea turtles in that hatchlings do not emerge from the nest until most or all of the clutch has hatched, which may make them particularly susceptible to fire ants. Of all eggs hatched, $100 \%$ of those from control groups survived, while only $29 \%$ of those in the fire ant infested enclosures survived. Hatchlings were most susceptible to fire ant predation while still in the egg after pipping. While fire ants were not able to breach an intact eggshell, they entered the egg as soon as a hole was pipped. Similar results were observed in work with slider turtles. Buhlmann and Coffmann (2001) assessed the effects of fire ants on a species with delayed emergence, Trachemys scripta, in South Carolina. They found that the closer the nest was to a fire ant mound, the greater the percentage of eggs and hatchlings killed by Solenopsis invicta. Only 55\% of fertile eggs in fire ant infested areas hatched resulting in surviving turtles vs. $100 \%$ survival in the control areas. Fire ants established underground foraging tunnels to the nest and were "monitoring" the eggs for signs of hatching. While fire ants were unable to breach fully turgid, intact eggs, as soon as the eggs were pipped they entered the nest and attacked hatchlings. Survival of overwintering turtle hatchlings in a nest frequented by fire ants is unlikely. Delayed emergence decreases hatchling mortality by providing a sanctuary from predators and harsh environmental conditions (Gibbons and Nelson, 1978). Fire ants may negate the value of the nest cavity as a sanctuary by establishing foraging tunnels into the cavity following egg laying.

Investigation into the potential impacts of fire ants on sea turtles has received more attention than most other reptile species. Allen et al. (2001a) sampled fire ants on sea turtle nesting beaches in Florida and found them present on 13 of 18 of the specific sampling sites. Work with Loggerhead turtles (Caretta caretta) in Georgia (Moulis, 1997) and Florida 
(Wilmers et al., 1996; Parris et al., 2002) as well as Green turtles (Chelonia mydas) in Florida (Wilmers et al., 1996) documented the increasing presence of fire ants in sea turtle nests. In Georgia a small percentage $(<11 \%)$ of turtle nests were infested with fire ants (Moulis, 1997), but the impacts on infested nests were considerable. The average hatchling release rate (defined as the number of hatchlings entering the water per number of eggs $\times 100$ ) was significantly lower $(15 \%)$ in nests infested with fire ants. Ants entered the nests just prior to hatchling emergence and it was assumed that as hatchlings pipped they were attacked by fire ants. Parris et al. (2002) documented fire ants stinging and consuming loggerhead hatchlings that had recently pipped. They also found skeletonized hatchlings that were consumed before they emerged from the nest. Hatchlings also sustained injuries including blinding and wounds on flippers and heads due to stinging that may have influenced survival (Parris et al., 2002).

Little has been published concerning the impacts of fire ants on amphibian populations (Freed and Neitman, 1988), but amphibians appear to be a highly vulnerable taxon. Observations of the endangered Houston toad, Bufo houstonensis, in Texas documented fire ant predation on newly-metamorphosed toadlets (Freed and Neitman, 1988, not included in Allen $e t$ al., 1994). Toadlets were attacked by fire ants as they emerged on the shore or on surface vegetation while older toadlets $(\sim 1 \mathrm{wk}$ old $)$ were observed evading fire ants.

Impacts on snakes and lizards have received more attention than amphibians (Conners, 1998b; Donaldson et al., 1994; Tuberville et al., 2000). The red imported fire ant has been implicated in the decline of the Texas horned lizard (Phrynosoma cornutum) (Donaldson et al., 1994), the southern hognose snake (Heterodon simus) (Tuberville et al., 2000) and the peninsular intergrade kingsnake (Lampropeltis getula floridanus) (Wojcik et al., 2001). For each species, the decline coincided with the invasion of red imported fire ants, but experimental evidence is lacking. The current and future status of Texas horned lizards was evaluated using museum specimens, historical records, surveys and resident interviews (Donaldson et al., 1994). This particular species is a dietary specialist that feeds predominately on harvester ants of the genus Pogonomyrmex and was historically found throughout the state of Texas. Reasons suggested for its decline include direct and indirect impacts from the invasion of red imported fire ants. Fire ants may decrease the availability of prey (i.e., harvester ants) as well as attack and prey upon incubating eggs and hibernating individuals. Webb and Henke (2003) documented two defensive strategies utilized by the Texas horned lizard (Phrynosoma cornutum) when confronted with fire ants. The two strategies appear to be dependent upon the number of fire ants present. In the first strategy, horned lizards ate fire ants ("consumption strategy") when there were $\leq 12$ fire ants present. In the second strategy, horned lizards ran away ("fleeand-bury") when $>20$ fire ants attacked. Both strategies appear to frustrate attacks by fire ants on Texas horned lizards (Webb and Henke, 2003). The southern hognose snake is a highly fossorial, egg-laying species that may also be vulnerable to the impacts of fire ants. Tuberville et al. (2000) found that the decline and extirpation of this snake from many parts of its range is concurrent with the range expansion of fire ants and suggests future research into the potential impacts on eggs and fossorial adults. Conners (1998b) suggested that fire ants were most likely responsible for the failure of more than half of a clutch of rough green snake (Opheodrys aestivus) eggs found collapsed after ants built a mound over their nest.

\section{IMPACTS ON BIRDS}

Direct and indirect impacts from fire ants have been documented on birds (Allen $e t$ al., 1994), and most attention has focused on the northern bobwhite. Allen et al. (1994) 
reviewed the literature pertaining to fire ant impacts on birds, finding 20 sources published between 1933 and 1993. However, of those, only five were peer-reviewed articles (Allen et al., 1994) and only one was experimental (a "before and after" natural experiment) (Sikes and Arnold, 1986). Since 1994, there has been a dramatic increase in the number of peer-reviewed papers $(n=21)$, and many of those studies provided experimental evidence for the impact of fire ants upon birds.

Northern bobwhite (Colinus virginianus) has been the subject of much of the research on the impacts of fire ants on birds. Brennan (1993) suggested that the relationship between northern bobwhite decline and fire ants was a "red herring" because there was not enough evidence to conclude that there was any real connection between the decline and fire ant abundance. Allen et al. $(1993,1995)$ refuted those claims and highlighted the need for additional manipulative research. In response to this debate, and continued northern bobwhite decline, several other studies have also been conducted on fire ants and bobwhites over the past 10 y. Allen et al. (1995) evaluated abundance trends from 1966-1992 for bobwhites in Texas. They found that in counties where fire ants were not yet present, bobwhite abundance was stable over this period. However, in counties where fire ants were present, bobwhite abundance was declining precipitously and the number of years a county had been infested with fire ants explained $75 \%$ of the variation (decline) in northern bobwhite abundance. Allen et al. (1995) also experimentally reduced fire ant abundance on ten 202 ha study areas, and by the second year of monitoring, bobwhite density was twice as high on treated areas. Additionally, Allen et al. (2000) evaluated bobwhite abundance before and after fire ant invasion in the southeastern United States and reported that bobwhites declined in response to fire ant invasion in the southeastern U.S. as a region, and in South Carolina and Florida, but not in Georgia. Several researchers have investigated the mechanisms for impact by fire ants on northern bobwhites. Giuliano et al. (1996) demonstrated that bobwhite chicks stung by fire ants exhibited reduced survival rates, and surviving chicks had reduced body mass. Bobwhite chicks exposed to 50 fire ants for $60 \mathrm{~s}$ and 200 fire ants for $15 \mathrm{~s}$ had significantly reduced survival rates, and these exposures corresponded to a range of only 6 to 22 fire ants attacking an individual chick (Giuliano $e t$ al., 1996). At the higher levels of exposure (200 fire ants for $60 \mathrm{~s}$ ), chicks exhibited reduced weight gain (Giuliano et al., 1996).

Pedersen et al. (1996) examined the response of pen-raised bobwhite chicks to the presence of fire ants. They compared chick behavior in control areas and areas where fire ants were suppressed. Fire ants altered daily activities of bobwhite chicks; bobwhite chicks in control areas spent less time sleeping, with more time walking and responding to fire ants, than chicks in plots where fire ants were suppressed. Mueller et al. (1999) compared hatching success and survival of bobwhite chicks for $2 \mathrm{y}$, under natural and suppressed fire ant conditions. They reported that bobwhite chick survival increased in areas where fire ants were suppressed. In particular, the proportion of chicks surviving to $21 \mathrm{~d}$ was higher for nests treated for fire ants than untreated nests. Mueller et al. (1999) also reported that the probability of chick survival decreased as the amount of fire ant activity increased in a nest. In another recent study, in 1997 and 1998, researchers compared hatching success from treated and untreated bobwhite nests (Dabbert et al., 2002). Only 2\% of chicks were killed while hatching from nests untreated for fire ants, but survival of chicks to $21 \mathrm{~d}$ from treated nests $(60 \%)$ was far greater than chicks from untreated nests (22\%) (Dabbert et al., 2002). Thirtyeight percent of bobwhite chick mortality was attributed to fire ant stings (Dabbert $e t$ al., 2002).

Limited research has focused upon the interaction between fire ants and loggerhead shrikes (Lanius ludovicianus). Lymn and Temple (1991; not included in Allen et al., 1994) 
suggested that loggerhead shrike numbers were lower in habitats after fire ant invasion in counties bordering the Gulf of Mexico. They speculated that the reason for this decline was due to competition with fire ants for food, primarily invertebrates (Lymn and Temple, 1991). However, Yosef and Lohrer (1995) did not observe fire ants attacking or killing eggs, nestlings, fledglings or adult shrikes in central Florida. Their study compared fire ant colony densities to shrike territory size, number of nesting attempts per season, total number of eggs laid per pair, number of young fledged per pair, prey capture rates of adult shrikes and percent of total time spent in flight either changing perches or in pursuit of prey. They concluded that varying fire ant mound densities had no effect on any of the variables analyzed and, thus, fire ants did not influence the reproductive success of loggerhead shrikes (Yosef and Lohrer, 1995). However, their comparisons of fire ant density and shrike breeding parameters had low statistical power $($ mean $=0.11$ ), which made the possibility of detecting fire ant impacts on shrike behavior unlikely. Additionally, the (1995) reported density of up to 13 fire ant mounds $/ \mathrm{m}^{2}$ exceeds any published reports of fire ant density by many orders of magnitude. In contrast, Allen et al. (2001b) reported greater invertebrate abundance and diversity and loggerhead shrike abundance on sites treated to reduce fire ant populations as compared with sites untreated for fire ants. The latter authors suggested that the mechanism of impact on shrikes was through a reduction of native invertebrates that served as food for shrikes; shrike abundance was negatively correlated with invertebrate abundance as assessed by light traps. The authors also included an observation of shrikecached food consumed by fire ants prior to the return of the bird that cached the insect (Allen et al., 2001b).

In a comparison between two sites (one island and half of another island) treated with fenoxycarb for fire ants and sites (one island and the other half of the treatment island) untreated for fire ants on spoil islands used as nesting colonies by waterbirds (Casmerodius albus; Ardea herodis; Phalacrorox olivaceus; Egretta thula; Hydranassa tricolor, Ajaia ajaja; Larus atricilla; Gelochelidon nilotica; Sterna forsteri), fire ants had little effect on mortality of young birds before the end of May (Drees, 1994). However, during June and July of both $y$ of the study, fire ants reduced waterbird production by $92 \%$ on the untreated sites (Drees, 1994). The lack of early-season mortality was likely influenced by temperature because fire ants are less active in cooler temperatures. As well, fire ant protein needs increase when they have brood in their colonies, which occurs late in the spring and throughout the summer months.

Fire ants have also been documented to cause mortality of least tern (Sterna antillarum) chicks (Lockley, 1995; Krogh and Schweitzer, 1999). Lockley (1995) conducted an experiment between least tern nesting sites on a continuous beach in Mississippi. He compared one site treated for fire ants with fenoxycarb and one site untreated for fire ants. Least tern chicks suffered $33 \%$ mortality on the site untreated for fire ants and $6.3 \%$ mortality on sites treated for fire ants (Lockley, 1995). Krogh and Schweitzer (1999) observed fire ants biting chicks and also found chicks partially consumed by fire ants, but were unable to determine if fire ants killed the chicks.

Several other species of birds are known to suffer from impacts by fire ants. Kopachena et al. (2000) documented 25\% mortality for barn swallow (Hirundo rustica) chicks at one site in Texas. Interestingly, they also noted that there was no mortality of barn swallows at another site in their study with three times the density of fire ant mounds (Kopachena $e t$ $a l ., 2000)$. Further, the researchers reported that data pre- and post-invasion by fire ants suggested no long-term effects on barn swallow populations (Kopachena et al., 2000). Dickinson (1995) observed two instances of fire ants preying on the newly hatched young of crested caracaras (Caracara plancus) in Texas. Dickinson and Arnold (1996) 
documented the occurrence of seven crested caracara nests in Texas. Of the nests $(n=5)$ laid between January and March, $72.6 \%$ were successful, while overall nest success was 45.7\% (Dickinson and Arnold, 1996). Dickinson and Arnold (1996) reported that predation by fire ants on caracara nestlings resulted in reduced nesting success for nestlings hatching in June. Fire ants have been implicated as a cause for the decline of common ground doves (Columbina passerina) in South Carolina (Cely and Glover, 2000). Fire ants were observed in Florida preying on a hatchling black rail (Laterallus jamaicensis) as it emerged from its egg (Legare and Eddleman, 2001). Legare and Eddleman (2001) noted that fire ant mounds were constructed under 16\% (three nests) of the black rail nests in their study area. Twedt et al. (2001) implicated fire ants as predators of forest birds in Mississippi including, but not limited to, blue-gray gnatcatchers (Polioptila caerulea), eastern towhees (Pipilo erythrophthalamus), indigo buntings (Passerina cyanea), northern cardinals (Cardinalis cardinalis) and yellow-billed cuckoos (Coccyzus americanus). While their study did not address specific predators of forest birds, they reported that fire ants were present in managed cottonwood stands, but absent from bottomland hardwood stands (Twedt et al., 2001). Fire ants were implicated in 58\% of predation events and $11 \%$ of nest failures in managed cottonwoods, which created a significant difference in predation rates between managed cottonwood and bottomland hardwood stands. Stake and Cimprich (2003) monitored black-capped vireo (Vireo atricapillus) nests by video surveillance for $3 \mathrm{y}$ in Texas. They reported that fire ants predominantly visited vireo nests at night (92\% of visits) and were responsible for $31 \%(\mathrm{n}=15)$ of nest depredations on black-capped vireo nests at Fort Hood, Texas.

\section{IMPACTS ON MAMMALS}

Prior to the 1960s, all reports of fire ant impacts on mammals were anecdotal. In the late 1960 s and early 1970s, two reports were published, one documenting negative impacts on cottontail rabbits (Hill, 1970) and one suggesting no impacts on muskrats (Newsom et al., 1976). In the 1980s, researchers began concerted efforts to assess fire ant impacts on mammals, especially small mammals, following reports of significant losses of live-trapped mice to fire ants in Texas (Masser and Grant, 1986; Flickinger, 1989).

Killion et al. (1995) removed fire ants (by directly treating each mound) from a 1.43 ha plot of brush prairie in coastal Texas and monitored small mammals in grids on either side of a barrier fence through the middle of the treated area. Season and fire ant density were both significant predictors of northern pygmy mouse (Baiomys taylori) captures. Additionally, recruitment time of fire ants to Baiomys burrows was slower than recruitment to random points and the number of new Baiomys captures was higher on sites with lower fire ant densities. Killion and Grant (1993) also documented a significant negative association between pygmy mice captures and fire ant mound densities when analyzed at a $100 \mathrm{~m}^{2}$ spatial resolution, but not when analyzed at 400 or $900 \mathrm{~m}^{2}$, but found no association between pygmy mice and ant foraging activity at any spatial scale. Ferris et al. (1998) investigated the impact fire ant abundance on small mammal captures at broad spatial scales. They established 15 sampling stations along $83 \mathrm{~km}$, capturing a gradient of fire ant mound densities. Total captures of small mammals were negatively related to fire ant mound density. Based on data published in theses or dissertations, they suggested that hispid cotton rats (Sigmodon hispidus) may be relatively "immune" to fire ant impacts, in contrast to other native small mammals. However, Pedersen et al. (2003) documented that $S$. hispidus altered habitat use in the summer in the presence of fire ants, but not in the winter, and that $B$. taylori exhibited no change in habitat use with fire ants present regardless of season. Wilkins and Broussard (2000) noted that $80 \%$ of their small mammal 
traps in grassland habitat in central Texas were 'infested' with fire ants. In all habitats in two study sites, small mammal species richness was lower than expected and previously documented and trap success was lower than for similar habitats elsewhere. Fire ants, along with overabundance of deer and other disturbance were suggested as potential causes.

Two studies have investigated the influence of fire ants on small mammal foraging behavior. Lechner and Ribble (1996) combined laboratory and field studies to assess behavioral interactions between fire ants and three small mammal species. In the laboratory, the authors conducted studies in a Y-shaped maze, where crushed fire ants were present in the end of one of the maze arms. They found that Baiomys taylori avoided the arm of the maze with fire ants present, whereas Sigmodon hispidus and Peromyscus leucopus were indifferent to the presence of crushed fire ants. Peromyscus used in the maze experiments were released after trials, trailed to their escape refuges or burrows and the distance to the nearest fire ant mound was measured. Distance of mounds from Peromyscus refuges and from random points did not differ. Additional field-work compared densities of fire ants to small mammal captures in a trapping grid of $6,150 \mathrm{~m}$ transects with paired traps. On this large grid, there was no significant relationship between fire ant mound density and small mammal abundance, but there was a hint of a slight positive association, suggesting, the authors believe, that fire ants and small mammals were responding to the same favorable habitat conditions. A second field component used smaller 6 by 6 small mammal trapping grids. Here too there were low capture rates. There was no relationship between captures and fire ant density at a $100 \mathrm{~m}^{2}$ scale, but at the $400 \mathrm{~m}^{2}$ scale there was a negative correlation between fire ants and Baiomys, and at a $900 \mathrm{~m}^{2}$ scale all species were negatively associated with fire ants.

Holtcamp et al. (1997) documented behavioral tradeoffs in Peromyscus when foraging in the presence of fire ants. With fire ants present, mice tended to spend more time in, visit more often and harvest more seeds from rich patches. In the absence of fire ants, those variables (\# visits, proportion seeds removed, time) did not differ between rich and poor patches. With fire ants present, mice left a given patch at lower final seed densities, thus attaining a higher within patch 'harvest' rate indicating that mouse foraging was more efficient in the presence of fire ants. Also, with fire ants present, mice spent more time handling seeds out of patches, as fire ants were confined to patch areas (about three times more often mice moved from the patch to consume a seed with fire ants present when compared without). But, despite spending more time handling seeds, that is moving out of patches to consume seeds, there was no difference in net yield with fire ants present because mice concentrated efforts in rich patches. This suggested that in the wild there may be a significant cost to foraging in the presence of fire ants.

There was only one experimental investigation of impacts on mammals, other than rodents, in the past decade. In the coastal plain of Texas, in areas of predominantly polygyne fire ants with densities of about 200 mounds/ha, Allen et al. (1997a) established five pairs of 202 ha study sites. One member of each pair was randomly selected and treated to reduce fire ant populations via aerial treatments with hydramethylnon (Amdro ${ }^{\circledR}$ ). Pretreatment and post-treatment fire ant and deer fawn recruitment (fawns/doe) were monitored. Fire ant populations were reduced following treatments and fawn recruitment was higher on treated areas as compared to untreated areas following treatment (about 2 times higher on treated areas). Additionally, fawn recruitment was negatively associated with June indices of fire ant abundance. One y after treatments stopped, fire ant populations were again similar on treated and untreated sites and fawn recruitment did not significantly differ (Allen, unpubl.). The authors suggested mechanisms for the documented impact, 
blinding and debilitating injury of fawns due to their behavioral reaction to danger of 'freezing' and increased coyote predation caused by increased fawn movements in reaction to the irritation of stings. Mueller et al. (2001) provided observations in support of the latter "increased movement" hypothesis. Mueller et al. (2001) observed a fawn with apparent irritation to the hindquarters running across a pasture in Texas during the middle of the day. Capture of the fawn revealed fire ants on its hindquarters. The authors suggested the fawn was running due to fire ant irritation and was vulnerable to predation because of movement during the day and animation of the doe associated with irritation of the hindquarters (e.g., scratching).

\section{SYNTHESIS}

The evidence suggests that some vertebrates are more likely to experience negative population-level impacts from fire ants than others. The hatching/birthing period is particularly hazardous for most species. Egg-laying species are probably more vulnerable than live-bearing species, ground-nesting species more vulnerable than canopy nesting species and altricial young more vulnerable than precocial young. Species that breed and live in open habitats are more vulnerable than species living in closed canopied habitats, which tend to have much lower fire ant densities. The timing of hatching/birthing may also be a factor in effects. Species that are born when fire ants are most active and when fire ants have brood and, thus, increased protein needs, are most vulnerable. Adult vertebrates may be vulnerable as well, though predation is rarely the mechanism. Fossorial species are more likely to be affected than terrestrial species. Adults, however, may be displaced by irritation resulting from stings and food availability may be decreased, especially for insectivores. Behavior also affects the vulnerability of a species to impacts. Inappropriate defensive behaviors such as freezing when danger is sensed (e.g., deer fawns) clearly can affect the outcome of contact between wildlife and fire ants. Reptile species whose young stay in underground nests until all the young have hatched prior to emergence are vulnerable, as are those that overwinter in their nests.

The increased level of research has led to information that can lead to better management of potentially affected species. However, the expense required for large scale fire ant treatments, along with the potential non-target impacts of substances available to reduce fire ant populations and the rapid recovery of fire ant populations even where successfully suppressed, make fire ant population reductions to benefit wildlife practical only under limited circumstances. Where a potentially impacted species has a very limited range (e.g., Lower Keys marsh rabbit, Sylvilagus palustris hefneri, Big Pine Key ringneck snake, Diadophis punctatus acricus; Forys et al., 2002) or where breeding aggregations occur (e.g., least tern Sterna antillarum; Lockley, 1995) fire ants may be controlled relatively effectively and cheaply with a variety of baits (Williams et al., 2001). Bait application techniques that incorporate methods of precision targeting can reduce the potential of affecting any non-target species, including native ant species, to near zero.

Despite a large increase in the volume of research over the past decade, knowledge gaps remain. Little research has been conducted on the impacts of fire ants on mammals other than small mammals in Texas. Similarly, only one observational study focused on fire ant impacts on amphibians. We suspect that amphibians are an especially vulnerable taxon, and research of population-level impacts of fire ants on vulnerable amphibian species should be initiated. As well, little is known of long-term impacts. Assessing the ecological impacts of fire ants on wild animal populations is logistically difficult, and very few studies have combined replicated experimental manipulation with adequate spatial ( $>10 \mathrm{ha})$ and temporal ( $>1$ y) scales (Table 1). Thus, most studies have been observational, opportunistic, 
TABLE 1.-Summary of research published 1993-2003 on fire ant-wildlife interactions. Wildlife species studies are listed alphabetically for reptiles and amphibians, birds and mammals

\begin{tabular}{|c|c|c|c|c|c|}
\hline Species & Impact & Study type & Extent & Duration & Citation \\
\hline $\begin{array}{l}\text { Alligator } \\
\quad \text { mississippiensis }\end{array}$ & $\begin{array}{l}\text { hatchling survival/ } \\
\text { weight gain }\end{array}$ & experimental & $<1$ ha & $<1 \mathrm{y}$ & Allen et al. $1997 \mathrm{~b}$ \\
\hline $\begin{array}{l}\text { Alligator } \\
\quad \text { mississippiensis }\end{array}$ & $\begin{array}{l}\text { nest success/ } \\
\text { female attendance }\end{array}$ & $\begin{array}{l}\text { natural } \\
\text { experiment }\end{array}$ & $>10$ ha & $>1 \mathrm{y}$ & Reagan et al. 2000 \\
\hline Bufo houstonensis & juvenile predation & observational & $<1$ ha & $<1 \mathrm{y}$ & $\begin{array}{l}\text { Freed and } \\
\quad \text { Neitman } 1988^{1}\end{array}$ \\
\hline Caretta caretta & hatchling predation & observational & $>10$ ha & $>1 \mathrm{y}$ & Moulis 1997 \\
\hline Caretta caretta & hatchling predation & observational & $>10$ ha & $>1 \mathrm{y}$ & Parris et al. 2002 \\
\hline Caretta caretta & hatchling predation & observational & $>10$ ha & $>1 \mathrm{y}$ & Wilmers et al. 1996 \\
\hline Caretta caretta & co-occurrence & observational & $>10$ ha & $>1 \mathrm{y}$ & Allen et al. 2001a \\
\hline Chelonia mydas & hatchling predation & observational & $>10$ ha & $>1 \mathrm{y}$ & Wilmers et al. 1996 \\
\hline Chelonia mydas & co-occurrence & observational & $>10$ ha & $>1 \mathrm{y}$ & Allen et al. 2001a \\
\hline Chelydra serpentina & hatchling predation & observational & $<1$ ha & $<1 \mathrm{y}$ & Conners 1998a \\
\hline Gopherus polyphemus & juvenile survival & observational & $>10$ ha & $>1 \mathrm{y}$ & $\begin{array}{l}\text { Epperson and } \\
\text { Heise } 2003\end{array}$ \\
\hline Heterodon simus & $\begin{array}{l}\text { abundance/ } \\
\text { distribution }\end{array}$ & observational & $>10$ ha & $>1 \mathrm{y}$ & $\begin{array}{l}\text { Tuberville et al. } \\
\quad 2000\end{array}$ \\
\hline Lampropeltis getula & abundance & observational & $>10$ ha & $>1 \mathrm{y}$ & Wojcik et al. 2001 \\
\hline Opheodrya aestivus & egg predation & observational & $<1$ ha & $<1 \mathrm{y}$ & Conners 1998b \\
\hline Phrynosoma cornutum & $\begin{array}{l}\text { abundance/ } \\
\text { distribution }\end{array}$ & observational & $>10$ ha & $>1 \mathrm{y}$ & $\begin{array}{l}\text { Donaldson et al. } \\
\quad 1994\end{array}$ \\
\hline Phrynosoma cornutum & defense strategy & observational & $>10$ ha & $>1 \mathrm{y}$ & $\begin{array}{l}\text { Webb and Henke } \\
2003\end{array}$ \\
\hline Psuedemys nelsoni & $\begin{array}{l}\text { hatchling survival/ } \\
\text { weight gain }\end{array}$ & experimental & $<1$ ha & $<1$ y & Allen et al. 2001a \\
\hline Pseudomys texana & nesting interference & observational & $<1$ ha & $<1 \mathrm{y}$ & Whiting 1994 \\
\hline Terrapene carolina & adult predation & observational & $>10$ ha & $>1 \mathrm{y}$ & Montgomery 1996 \\
\hline Trachemys scripta & hatchling survival & experimental & $<1$ ha & $<1 \mathrm{y}$ & $\begin{array}{l}\text { Buhlmann and } \\
\text { Coffman } 2001\end{array}$ \\
\hline Caracara plancus & survival & observational & $>10$ ha & $<1 \mathrm{y}$ & Dickinson 1995 \\
\hline Caracara plancus & survival & observational & $>10$ ha & $<1 \mathrm{y}$ & Dickinson 1996 \\
\hline Colinus virginianus & abundance & anecdotal & $>10$ ha & $>1 \mathrm{y}$ & Allen et al. 1993 \\
\hline Colinus virginianus & abundance & anecdotal & $>10$ ha & $>1 \mathrm{y}$ & Brennan 1993 \\
\hline Colinus virginianus & abundance & $\begin{array}{l}\text { experimental/ } \\
\text { natural } \\
\text { experiment }\end{array}$ & $>10$ ha & $>1 \mathrm{y}$ & Allen et al. 1995 \\
\hline Colinus virginianus & survival/behavior & experimental & laboratory & $<1 \mathrm{y}$ & Giuliano et al. 1996 \\
\hline Colinus virginianus & foraging behavior & experimental & $<10$ ha & $<1 \mathrm{y}$ & Pedersen et al. 1996 \\
\hline Colinus virginianus & survival & experimental & $>10$ ha & $>1 \mathrm{y}$ & Mueller et al. 1999 \\
\hline Colinus virginianus & survival & experimental & $<10$ ha & $>1 \mathrm{y}$ & Dabbert et al. 2002 \\
\hline Colinus virginianus & abundance & $\begin{array}{l}\text { natural } \\
\text { experiment }\end{array}$ & $>10$ ha & $>1 \mathrm{y}$ & Allen et al. 2000 \\
\hline Columbina passerina & survival & anecdotal & $>10$ ha & $>1 \mathrm{y}$ & $\begin{array}{l}\text { Cely and Glover } \\
2000\end{array}$ \\
\hline Hirundo rustica & survival & observational & $<10$ ha & $<1 \mathrm{y}$ & $\begin{array}{l}\text { Kopachena et al. } \\
2000\end{array}$ \\
\hline Lanius ludovicianus & abundance & $\begin{array}{l}\text { natural } \\
\text { experiment }\end{array}$ & $>10$ ha & $>1 \mathrm{y}$ & $\begin{array}{l}\text { Lymn and Temple } \\
1991^{1}\end{array}$ \\
\hline Lanius ludovicianus & abundance & experimental & $>10$ ha & $>1 \mathrm{y}$ & Allen et al. 2001b \\
\hline
\end{tabular}


TABLE 1.-Continued

\begin{tabular}{|c|c|c|c|c|c|}
\hline Species & Impact & Study type & Extent & Duration & Citation \\
\hline Lanius ludovicianus & $\begin{array}{c}\text { abundance/ } \\
\text { behavior }\end{array}$ & observational & $>10$ ha & $>1 \mathrm{y}$ & $\begin{array}{l}\text { Yosef and Lohrer } \\
1995\end{array}$ \\
\hline Laterallus jamaicensis & survival & observational & $>10$ ha & $>1 \mathrm{y}$ & $\begin{array}{l}\text { Legare and } \\
\text { Eddleman } 2001\end{array}$ \\
\hline Sterna antillarum & survival & experimental & $<10$ ha & $>1 \mathrm{y}$ & Lockley 1995 \\
\hline Sterna antillarum & survival & observational & $<10$ ha & $>1 \mathrm{y}$ & $\begin{array}{l}\text { Krogh and } \\
\text { Schweitzer } 1999\end{array}$ \\
\hline Forest birds & survival & observational & $>10$ ha & $>1 \mathrm{y}$ & Twedt et al. 2001 \\
\hline Vireo atricapillus & nestling predation & observational & $>10$ ha & $>1 \mathrm{y}$ & $\begin{array}{l}\text { Stake and } \\
\quad \text { Cimprich } 2003\end{array}$ \\
\hline waterbirds & $\begin{array}{l}\text { abundance/ } \\
\text { behavior }\end{array}$ & experimental & $<10$ ha & $>1 \mathrm{y}$ & Drees 1994 \\
\hline Baiomys taylori & $\begin{array}{l}\text { capture rate/ } \\
\text { abundance }\end{array}$ & experimental & $<10$ ha & $<1 \mathrm{y}$ & Killion et al. 1995 \\
\hline Baiomys taylori & capture rate & $\begin{array}{l}\text { natural } \\
\text { experiment }\end{array}$ & $<10$ ha & $<1$ y & $\begin{array}{l}\text { Killion and Grant } \\
1993\end{array}$ \\
\hline Odocoileus virginianus & recruitment & experimental & $>10$ ha & $>1 \mathrm{y}$ & Allen et al. 1997a \\
\hline Odocoileus virginianus & movement & observational & $<1$ ha & $<1 \mathrm{y}$ & Mueller et al. 2001 \\
\hline Peromyscus maniculatus & foraging behavior & experimental & laboratory & $<1 \mathrm{y}$ & Holtcamp et al. 1997 \\
\hline $\begin{array}{l}\text { Sigmodon hispidus- } \\
\text { other }\end{array}$ & capture rate & $\begin{array}{l}\text { natural } \\
\text { experiment }\end{array}$ & $>10$ ha & $<1 y^{2}$ & Ferris et al. 1998 \\
\hline Sigmodon hispidus/ & foraging behavior & experimental & 10 ha and & $<1 \mathrm{y}$ & $\begin{array}{l}\text { Lechner and } \\
\text { Ribble } 1996\end{array}$ \\
\hline \multicolumn{6}{|l|}{ Baiomys taylori/ } \\
\hline Peromyscus leucopus & foraging behavior & experimental & laboratory & & \\
\hline \multicolumn{6}{|l|}{ Sigmodon hispidus/ } \\
\hline Baiomys taylori & habitat use & experimental & $>10$ ha & $>1 \mathrm{y}$ & Pedersen et al. 2003 \\
\hline Small mammals & capture rate & observational & $>10$ ha & $<1 y^{2}$ & $\begin{array}{l}\text { Wilkins and } \\
\text { Broussard } 2000\end{array}$ \\
\hline
\end{tabular}

\footnotetext{
${ }^{1}$ Not included in Allen et al. (1994)

${ }^{2}$ Sampling in this study lasted for 13 mo
}

small-scale or 'natural' experiments. They lack the statistical power to detect more subtle impacts (modest effect sizes), but these relatively small—but incremental-impacts may be very substantial. Our knowledge has significantly increased, but we still know relatively little concerning the complex impacts fire ants may have on native wildlife and ecosystems.

Acknowledgments.-The South Carolina Cooperative Fish and Wildlife Research Unit is jointly supported by a cooperative agreement between the United States Geological Survey/Biological Resources Division, South Carolina Department of Natural Resources, Clemson University and the Wildlife Management Institute.

\section{Literature Cited}

Allen, C. R., R. S. Lutz And S. Demarais. 1993. What about fire ants and northern bobwhites. Wildl. Soc. Bull., 21:349-351. 
, S. Demarais And R. S. Lutz. 1994. Red imported fire ant impact on wildlife: an overview. Tex. J. Sci., 46:51-59.

- R. S. Lutz and S. Demarais. 1995. Red imported fire ant impacts on northern bobwhite populations. Ecol. Appl., 5:632-638.

— S. Demarais and R. S. Lutz. 1997a. Effects of red imported fire ants on recruitment of whitetailed deer fawns. J. Wildl. Manage., 61:911-916.

—, K. G. Rice, D. P. Wojcik and H. F. Percival. 1997b. Effect of red imported fire ant envenomization on neonatal American alligators. J. Herp., 31:318-321.

—, R. D. Willey, P. E. Myers, P. M. Horton and J. Buffa. 2000. Impact of red imported fire ant infestation on northern bobwhite quail abundance trends in southeastern United States. J. Agric. Urb. Entomol., 17:4351.

—, E. A. Forys, K. G. Rice And D. P. Wojcik. 2001a. Effects of fire ants (Hymenoptera:Formicidae) on hatching turtles and prevalence of fire ants on sea turtle nesting beaches in Florida. Fla. Entomol., 84:250-253.

—, R. S. Lutz, T. Lockley, S. A. Phillips, Jr. and S. Demarais. 2001b. The non-indigenous ant, Solenopsis invicta, reduces loggerhead shrike and native insect abundance. J. Agric. Urb. Entomol., 18:249-259.

Brennan, L. A. 1993. Fire ants and northern bobwhites: a real problem or a red herring? Wildl. Soc. Bull., 21:351-355.

Buhlmann, K. A. and G. Coffman. 2001. Fire ant predation of turtle nests and implications for the strategy of delayed emergence. J. Elisha Mitchell Soc., 117:94-100.

Buren, W. F. 1972. Revisionary studies on the taxonomy of the imported fire ants. J. Ga. Entomol. Soc., 7:1-26.

- G. E. Allen, W. H. Whitcomb, F. E. Lennartz and R. N. Williams. 1974. Zoogeography of the imported fire ants. J. NY Entomol. Soc., 82:113-124.

Cely, J. E. AND L. Glover. 2000. Status and distribution of the common ground-dove in South Carolina. The Chat, 64:37-46.

Conners, J. S. 1998a. Chelydra serpentina (Common Snapping Turtle). Predation. Herp. Rev., 29: 235.

1998b. Opheodrys aestivus (Rough Green Snake). Egg predation. Herp. Rev., 29:243.

Dabbert, C. B., R. B. Mitchell, J. M. Mueller, A. R. Forbes and J. H. Treadway. 2002. Northern bobwhite and red imported fire ant interactions in the Texas coastal plains. Southwest. Entomol., 25: 105-110.

Davis, L. R., Jr., R. K. Vander Meer and S. D. Porter. 2001. Red imported fire ants expand their range across the West Indies. Fla. Entomol., 84:735-736.

Dickinson, V. M. 1995. Red imported fire ant predation on crested caracara nestlings in south Texas. Wilson Bull., 107:762-764.

- AND K. A. ARnold. 1996. Breeding biology of the crested caracara in south Texas. Wilson Bull., 108:516-523.

Donaldson, W., A. H. Price and J. Morse. 1994. The current status and future prospects of the Texas horned lizard (Phrynosoma cornutum) in Texas. Texas J. Sci., 46:97-113.

Drees, B. M. 1994. Red imported fire ant predation on nestlings of colonial waterbirds. Southwest. Entomol., 19:355-359.

Epperson, D. M. AND C. D. Heise. 2003. Nesting and hatchling ecology of gopher tortoises (Gopherus polyphemus) in southern Mississippi. J. Herp., 37:315-324.

Ferris, D. K., M. J. Killion, K. P. Ferris, W. E. Grant and S. B. Vinson. 1998. Influence of relative abundance of red imported fire ants (Solenopsis invicta) on small mammal captures. Southwest. Nat., 43:97-100.

FLICKINGER, E. L. 1989. Observation of predation by red imported fire ants on live-trapped wild cotton rats. Texas J. Sci., 41:223-224.

Forys, E. A., C. R. Allen AND D. P. Wojcik. 2002. Influence of the proximity and amount of human development and roads on the occurrence of the red imported fire ant in the lower Florida Keys. Biol. Conserv., 108:27-33. 
Freed, P. S. and K. Neitman. 1998. Notes on predation on the endangered Houston toad, Bufo houstonensis. Texas J. Sci., 40:454-456.

Gibbons, J. W. AND D. H. Nelson. 1978. The evolutionary significance of delayed emergence from the nest by hatchling turtles. Evolution, 32:297-303.

- D. E. Scott, T. Ryan, K. Buhlmann, T. Tuberville, J. Greene, T. Mills, Y. Leiden, S. Poppy, C. Winne AND B. MetTs. 2000. The global decline of reptiles, Déjà Vu Amphibians. BioScience, 50:653-666.

Giuliano, W. M., C. R. Allen, R. S. Lutz and S. Demarais. 1996. Effects of red imported fire ants on northern bobwhite chicks. J. Wildl. Manage., 60:309-313.

Greenberg, L., D. J. C. Fletcher and S. B. Vinson. 1985. Differences in worker size and mound distribution in monogynous and polygynous colonies of fire ant Solenopsis invicta Buren. J. Kansas Entomol. Soc., 58:9-18.

Handel, S. N., S. B. Fisch And G. E. Schatz. 1981. Ants disperse a majority of herbs in a mesic forest community in New York State. Bull. Torrey Bot. Club, 108:430-437.

Hill, E. P. 1970. Observations of imported fire ant predation on nestling cottontails. Proc. Southeast. Assoc. Game Fish Comm., 23:171-181.

Holldobler, B. and E. O. Wilson. 1990. The ants. The Belknap Press of Harvard University Press, Cambridge, Massachusetts. 732 p.

Holtcamp, W. N., W. E. GRANT AND S. B. VinSON. 1997. Patch use under predation hazard: effect of the red imported fire ant on deer mouse foraging behavior. Ecology, 308-317.

Holway, D. A., L. Lach, A. V. Suarez, N. D. Tsutsui and T. J. Case. 2002. The causes and consequences of ant invasions. Ann. Rev. Ecol. System., 33:181-233.

Jouvenaz, D. P. 1983. Natural enemies of fire ants. Fla. Entomol., 66:111-121.

, D. P. WojCiK ANd R. K. VAnder Meer. 1989. First observation of polygyny in fire ants, Solenopsis spp., in South America. Psyche, 96:161-165.

Killion, M. J. AND W. E. Grant. 1993. Scale effects in assessing the impact of imported fire ants on small mammals. Southwest. Nat., 38:393-396.

- AND S. B. VINSON. 1995. Response of Baiomys taylori to changes in density of imported fire ants. J. Mammal., 76:141-147.

Kopachena, J. G., A. J. Buckley and G. A. Potts. 2000. Effects of the red imported fire ant (Solenopsis invicta) on reproductive success of barn swallows (Hirundo rustica) in northeast Texas. Southwest. Nat., 45:477-482.

Krogh, M. G. ANd S. H. Schweitzer. 1999. Least terns nesting on natural and artificial habitats in Georgia, USA. Waterbirds, 22:290-296.

Landers, J. L., J. A. Garner and W. A. McRae. 1980. Reproduction of gopher tortoises (Gopherus polyphemus) in southwestern Georgia. Herpetologica, 36:353-361.

Lechner, K. A. AND D. O. RibBle. 1996. Behavioral interactions between red imported fire ants (Solenopsis invicta) and three rodent species of South Texas. Southwest. Nat., 41:123-128.

Legare, M. L. ANd W. R. Eddleman. 2001. Home range size, nest-site selection and nesting success of black rails in Florida. J. Field Ornithol., 72:170-177.

LOCKLEY, T. C. 1995. Effect of imported fire ant predation on a population of the least tern-an endangered species. Southwest. Entomol., 20:517-519.

Lymn, N. And S. A. Temple. 1991. Land-use changes in the Gulf coast region: links to declines in midwestern loggerhead shrike populations. Passenger Pigeon, 53:315-325.

Macom, T. E. And S. D. Porter. 1996. Comparison of polygyne and monogyne red imported fire ant (Hymenoptera: Formicidae) population densities. Ann. Entomol. Soc. Amer., 89:535-543.

Masser, M. P. And W. E. Grant. 1986. Fire ant-induced trap mortality of small mammals in East-central Texas. Southwest. Nat., 31:540-542.

McGLYNN, T. P. 1999. The worldwide transfer of ants: geographical distribution and ecological invasions. J. Biogeo., 26:535-548.

Moloney, S. And C. Vanderwoude. 2002. Red imported fire ants: a threat to eastern Australia's wildlife? Ecol. Manage. Restor., 3:167-175.

Montgomery, W. B. 1996. Predation by the fire ant, Solenopsis invicta, on the three-toed box turtle, Terrapene carolina triunguis. Bull. Chicago Herp. Soc., 31:105-106. 
Moulis, R. A. 1997. Predation by the red imported fire ant (Solenopsis invicta) on loggerhead sea turtle (Caretta caretta) nests on Wassaw National Wildlife Refuge, Georgia. Chel. Conserv. Biol., 2:433436.

Mueller, J. M., C. B. Dabbert, S. Demarais and A. R. Forbes. 1999. Northern bobwhite chick mortality caused by red imported fire ants. J. Wildl. Manage., 63:1291-1298.

— - AND A. R. Forbes. 2001. Negative effects of imported fire ants on deer: the "increased movement" hypothesis. Texas J. Sci., 53:87-90.

Newsom, J. D., H. R. Perry And P. E. Schilling. 1976. Fire ant-muskrat relationships in Louisiana coastal marshes. Proc. Southeast. Assoc. Game Fish Comm., 30:414-418.

Parris, L. B., M. M. LAmont and R. R. Carthy. 2002. Increased incidence of red imported fire ant (Hymenoptera:Formicinae) presence in loggerhead seas turtle (Testudines:Cheloniidae) nests and observations of hatchling mortality. Fla. Entomol., 85:514-517.

Pedersen, E. K., T. L. Bedford, W. E. Grant, S. B. Vinson, J. B. Martin, M. T. Longnecker, C. L. Barr AND B. M. DREES. 2003. Effect if red imported fire ants on habitat use by hispid cotton rats (Sigmodon hispidus) and northern pygmy mice (Baiomys taylori). Southwest. Nat., 48: 419-426.

—, W. E. GRAnt And M. T. Longnecker. 1996. Effects of red imported fire ants on newly-hatched northern bobwhite. J. Wildl. Manage., 60:164-169.

Pimentel, D., S. McNair, J. Janecka, J. Wightman, C. Simmonds, C. O’Connell, E. Wong, L. Russel, J. Zern, T. AQuina AND T. Tsomondo. 2001. Economic and environmental threats of alien plant, animal, and microbe invasions. Agric. Ecosyst. Environ., 84:1-20.

Porter, S. D., A. Bhatkar, R. Mulder, S. B. Vinson and D. J. Clair. 1991. Distribution and density of polygyne fire ants (Hymenoptera: Formicidae) in Texas. Econ. Entomol., 84:867-874.

- H. G. Fowler and W. P. MacKay. 1992. Fire ant mound densities in the United States and Brazil (Hymenoptera: Formicidae). J. Econ. Entomol., 85:1154-1161.

- D. F. Williams, R. S. Patterson and H. G. Fowler. 1997. Intercontinental differences in the abundance of Solenopsis fire ants (Hymenoptera: Formicidae): escape from natural enemies. Environ. Entomol., 26:373-384.

Reagan, S. R., J. M. Ertel and V. L. Wright. 2000. David and Goliath retold: fire ants and alligators. J. Herp., 34:475-478.

Ross, K. G., E. L. Vargo and L. Keller. 1996. Social evolution in a new environment: the case of introduced fire ants. Proc. Nat'l. Acad. Sci., 93:3021-3025.

Sikes, P. J. AND K. A. ARnOLD. 1986. Red imported fire ant (Solenopsis invicta) predation on cliff swallow (Hirundo pyrrhonata) nestlings in east-central Texas. Southwest. Nat., 31:105-106.

Stake, M. M. and D. A. Cimprich. 2003. Using video to monitor predation at black-capped vireo nests. Condor, 105:348-357.

Tuberville, T. D., J. R. Bodie, J. B. Jensen, L. LaClaire and J. W. Gibbons. 2000. Apparent decline of the southern hog-nosed snake, Heterodon simus. J. Elisha Mitchell Soc., 116:19-40.

Twedt, D. J., R. R. Wilson, J. L. Henne-Kerr and R. B. Hamilton. 2001. Nest survival of forest birds in the Mississippi alluvial valley. J. Wildl. Manage., 65:450-460.

Vinson, S. B. And A. A. Sorensen. 1986. Imported fire ants: life history and impact. Texas Department of Agriculture, Austin, Texas. 28 p.

Webb, S. L. ANd S. E. Henke. 2003. Defensive strategies of Texas horned lizards (Phrynosoma cornutum). Herp. Rev., 34:327-328.

Whiting, M. J. 1994. Pseudomys texana (Texas River Cooter). Nesting interference. Herpetol. Rev., 25:25.

Wilkins, K. T. AND D. R. BRoussard. 2000. Small mammals of the post oak savanna in East-central Texas. Texas J. Sci., 52:201-212.

Williams, D. F., H. L. Collins and D. H. Oi. 2001. The red imported fire ant (Hymenoptera: Formicidae): an historical perspective of treatment programs and the development of chemical baits for control. Amer. Entomol., 47:146-159.

Wilmers, T. J., E. S. Wilmers, M. Miller ANd P. Wells. 1996. Imported fire ants (Solenopsis invicta): a growing menace to seas turtle nests in Key West National Wildlife Refuge, p. 341-343. In: J. A. Keinath, D. E. Barnard, J. A. Musick and B. A. Bell (eds.). Proceedings of the $15^{\text {th }}$ Annual 
Published in AMERICAN MIDLAND NATURALIST 152 (2004), pp. 88-103

2004

Allen et Al.: Fire Ant Impacts

Workshop on Sea Turtle Biology and Conservation. U.S. Department of Commerce, NOAA Technical Memorandum NMFS-SEFSC.

Wojcik, D. P., C. R. Allen, R. J. Brenner, E. A. Forys, D. P. Jouvenaz and R. S. Lutz. 2001. Red imported fire ants: impact on biodiversity. Amer. Entomol., 47:16-23.

Yosef, R. And F. E. Lohrer. 1995. Loggerhead shrikes, red fire ants and red herrings? Condor, 97:10531056. 